Article

\title{
The Social Dimension of Security: The Dichotomy of Respondents' Perceptions during the COVID-19 Pandemic
}

\author{
Sławomir Kalinowski ${ }^{1, *}$, , Aleksandra Luczak $^{2} \mathbb{D}$ and Adam Koziolek ${ }^{3}$ \\ 1 Department of Rural Economics, Institute of Rural and Agricultural Development, \\ Polish Academy of Sciences, ul. Nowy Świat 72, 00-330 Warsaw, Poland \\ 2 Department of Finance and Accounting, Faculty of Economics, Poznań University of Life Sciences, \\ ul. Wojska Polskiego 28, 60-637 Poznan, Poland; aleksandra.luczak@up.poznan.pl \\ 3 Independent Researcher, 60-637 Poznan, Poland; a.koziolek@pwr.agro.pl \\ * Correspondence: skalinowski@irwirpan.waw.pl
}

check for

updates

Citation: Kalinowski, S.; Łuczak, A.; Koziolek, A. The Social Dimension of Security: The Dichotomy of Respondents' Perceptions during the COVID-19 Pandemic. Sustainability 2022, 14, 1363. https://doi.org/ $10.3390 /$ su14031363

Academic Editors: Tomasz Rokicki, Sebastian Saniuk and

Dariusz Milewski

Received: 2 January 2022

Accepted: 21 January 2022

Published: 25 January 2022

Publisher's Note: MDPI stays neutral with regard to jurisdictional claims in published maps and institutional affiliations.

Copyright: (C) 2022 by the authors. Licensee MDPI, Basel, Switzerland. This article is an open access article distributed under the terms and conditions of the Creative Commons Attribution (CC BY) license (https:// creativecommons.org/licenses/by/ $4.0 /)$.

\begin{abstract}
The main goal of the study was to make a subjective assessment of the social security of households during the coronavirus pandemic. In order to achieve this goal, a three-stage primary research based on the CAWI method (computer-assisted web interview) was conducted on households in Poland in April, June, and September 2020. The research used statistical methods of structure evaluation and the fuzzy TOPSIS method. It assessed the security of households and respondents' subjective perceptions of the loss of financial stability, income, and employment, as well as presenting the deterioration of the situation of their households in the immediate future. The respondents also assessed the possible deterioration of the situation in Poland, the growth of poverty in families and unemployment in the immediate future. In addition, the respondents' subjective assessments of the level of insecurity about the future of their households and the situation in Poland were quantified. One of the most important conclusions was the dichotomy in the respondents' perceptions, as they assessed the situation of their households better than the situation in Poland. The research shows that in April 2020, i.e., at the first stage of the research, the respondents strongly felt that the financial situation of their households had deteriorated. In June 2020 (stage II) this perception weakened slightly because they may have considered the pandemic situation to be temporary. However, in September 2020 (stage III) the sense of the possible deterioration of their financial situation increased again due to the ongoing pandemic and its consequences.
\end{abstract}

Keywords: dichotomy in perception; COVID-19; sense of insecurity; social security; socioeconomic situation; subjective poverty

\section{Introduction}

A society with a sense of security in all dimensions of its life seems to be only a literary fiction, as in Utopia by Thomas More. The reality of contemporary societies around the world lies outside the boundaries of Utopia and seems to be becoming a quasi-Orwellian anti-Utopia. It is manifested by restrictions of interpersonal contacts and the promotion of the 'Stay at home' slogan, as well as the preposterous closure of forests due to the epidemic. These restrictions increase poverty and limit the possibility of earning a living. In the real world, a dystopian vision of the past is beginning to emerge. It is an extrapolation of the existing social order and the world affected by the omnipresent sense of the slow disintegration of various systems and structures, including economic and social ones.

The alternative present and future are becoming real. Especially the 21st century brings both challenges and difficulties in meeting the requirements of contemporary times. One such challenge is the COVID-19 pandemic and the related restrictions and changes taking place in households (the micro scale) and the economies of individual countries (the macro scale). This period is undoubtedly a continuation of the changes which Bauman [1] described as liquid modernity. The variability of life, which was mentioned by Heraclitus 
many centuries ago, echoes in Bauman's investigations. The lack of stability and anchoring can be observed in various areas of life. Sometimes it is manifested as a lack of capital, other times as a lack of value or self-identity. Of course, these are not all aspects of these changes. There are noticeable changes in the housing market [2,3], as well as in monetary and fiscal policy $[4,5]$. Additionally, the structure of consumption and its character are changing [6-8]; the demand for products from nature-friendly production systems has changed [9]. Some interesting phenomena in this regard were observed during the COVID-19 pandemic. Hromada and Cermakova [10] stated that "the gap between household income and real estate prices is constantly widening" and "economic downturn is very different from all recent financial crises impact on property". The impact of the pandemic has also revealed itself in the banking sector [11] as well as in the market for agrotourism and tourism services [12,13]. Some tourists have begun to avoid travel, which can stoke ethnocentric sentiments as people begin to fear crowded destinations where the chance of encountering a sick person is greater [14,15]. However, it is necessary to ask whether Bauman was right to say that everything is changeable. This question will be left open for discussion so that readers can pause and consider an answer.

The changes that actually occur during the pandemic relate to actions both by individuals and entire societies. Individuals are looking for solutions that would rationalise their everyday life-a change in their daily routine, reorganisation of work, and changes in the education system. The actions of the authorities seeking to counteract the unfavourable phenomena in the economy and society are also adapted to the current situation. These problems affect countries with different standards of living. Enormous effort needs to be taken by individuals and entire societies to maintain a high standard of living in developed ountries.

These facts lead to reflection on the current socioeconomic situation, which affects people's security. There are numerous studies and articles indicating both people's adaptation to the reality of the COVID-19 pandemic and negating this phenomenon [16-24]. The period of insecurity caused by the COVID-19 pandemic and the related restrictions has continued for over a year, and nobody knows how people's lives will be influenced by changes in the global economy. The pandemic and related restrictions have affected people's personal, occupational, and social lives in various ways $[25,26]$. This article is the result of extensive research on people's situations during the COVID-19 pandemic. This period has become the quintessence of living under precarious conditions [27-30], when income, work, and future are the most serious causes of people's anxiety [31-36]. There are also problems with unavailable housing [37], and material deprivation has become commonplace [38-43].

The study was designed to investigate people's situations during the COVID-19 pandemic. The key issue was to determine how the economic changes and adaptation measures addressed at individuals, and indirectly at the enterprises in which the respondents were employed, affected the situation and consumption of households. The study presents changes in people's behaviour and the situation of their households resulting from the COVID-19 pandemic.

The main goal was to make a subjective assessment of the social security of households during the coronavirus pandemic. The authors were particularly interested in finding answers to the following main research questions:

RQ1: Do the respondents think that their financial situation deteriorated during the period under analysis?

RQ2: Do households fear poverty during the pandemic?

RQ3: Do the respondents think their employment situation is secure?

RQ4: What is the respondents' level of uncertainty about the future situation of their households and the socioeconomic situation in Poland?

Due to the intended multi-stage repetition of the research, additional goal was to observe changes at individual stages of the pandemic and whether the respondents' assessments were polarised. 
Hence the following research hypotheses were formulated:

Hypotheses 1 (H1). The respondents felt that the income situation of their households would deteriorate during the pandemic.

Hypotheses 2 (H2). The respondents' perception of poverty in their households will increase during the pandemic.

Hypotheses 3 (H3). The respondents feared losing their jobs and the increasing unemployment in Poland.

Hypotheses 4 (H4). During the period under analysis, the respondents felt highly uncertain of the future financial situation of their families and the socioeconomic situation in Poland.

Our three-stage primary research based on the CAWI method (Computer-Assisted Web Interview) was conducted on households in Poland in April, June, and September 2020. In summary, our contribution includes the following major aspects. We assessed the social security of the respondents' households during the coronavirus pandemic. The respondents' perceptions of the future of their households and their opinions about the future socioeconomic situation in Poland were analysed. We also developed a quantitative approach based on fuzzy multiple-criteria decision-making (MCDM) methods to assess the respondents' perceptions of insecurity of the future socioeconomic situation of their households and Poland as a whole. The research results are very important for governments, politicians, and other decision-makers involved in the prevention and reduction of the impact of the coronavirus pandemic.

The article (apart from the introduction) is structured as follows. Part 2 presents the data and methods used in the empirical study. Part 3 presents the results of the research on the respondents' subjective assessment of the social security of their households during the coronavirus pandemic. The authors also quantified the respondents' subjective level of the insecurity of the future socioeconomic situation of their households and Poland. Changes in the respondents' perceptions of the socioeconomic situation of their households and Poland depending on their place of residence and stage of survey were also taken into account. Part 4 is the discussion. Parts 5 and 6 contain conclusions and recommendations.

\section{Materials and Methods}

The empirical materials used in the article are part of a much wider primary research entitled My Situation During the Coronavirus Pandemic [44]. The research based on the CAWI (computer-assisted web interview) method was conducted from 9-15 April 2020 (stage I), 16-24 June 2020 (stage II) and 21-30 September 2020 (stage III). As it was difficult to contact respondents directly, the CAWI method was one of few options to learn about their situation. The method enabled the participation of a large group of respondents and ensured their anonymity. The following number of respondents took part in the research: stage I - 3086; stage II-1368; stage III-1431. The entire area of Poland was included in the research.

As the interest in the research on the situation of households in Poland was very high, over three thousand questionnaires were collected from respondents in stage I of the research. In the next two stages, the number of questionnaires received from the respondents decreased by more than a half. It is noteworthy that, by definition, not everyone was able to take part in the questionnaire survey (e.g., people without Internet access). Nevertheless, the survey enabled the observation of dependencies and changes in the behaviour of the population. The sample collected was not random, because it did not meet the postulates of procedural representativeness. However, the research assumption was that at each stage the sample should be representative-a quota sample according to the most important research criterion: the class of locality of a household. In order to achieve this goal, a quota sample structure was designed, and an appropriate number of households was recruited. The following classes of respondents' places of residence were assumed: village, small town with less than 20,000 residents, urban area 
with 20,000-99,999 residents, urban area with 100,000-499,999 residents, urban area with over 500,000 residents. The research assumption was that the structure of the sample should be similar to the population structure. Thus, 458 households were selected at each stage of the study, mapping the structure adopted in the Household Budget Survey in Statistics Poland [45].

In order to answer research questions RQ1-RQ3 and to verify research hypotheses RH1-RH3, statistical methods were used to compare the structures of answers to the questions about the subjective assessment of the respondents' sense of social security of their households. Structure indicators (percentages) were used, and their similarity was assessed with the Wilcoxon signed-rank test at a significance level $\alpha=0.05$. The Wilcoxon test verified the equality of medians (null hypothesis) for variables describing the socioeconomic situation of the household and Poland as a whole. In addition, the relative similarity coefficient was used to test the degree of similarity of the responses [46]:

$$
\operatorname{RSC}\left(w_{t}, w_{s}\right)=\frac{\sum_{j=1}^{P} \min \left(w_{j t}, w_{j s}\right)}{\sum_{j=1}^{P} \max \left(w_{j t}, w_{j s}\right)} .
$$

where: $w_{t}, w_{s}$-two vectors of response structures (in \%); $w_{t}=\left[w_{1 t}, w_{2 t}, \ldots, w_{P t}\right]^{T}$, $w_{s}=\left[w_{1 s}, w_{2 s}, \ldots, w_{P_{s}}\right]^{T}, P$ - the number of response variants in a question. The more similar the structures, the closer is the $\operatorname{RSC}\left(w_{t}, w_{s}\right)$. measure of similarity to 1 . When $\operatorname{RSC}\left(w_{t}, w_{s}\right)=1$, the structures are identical. Table 1 shows the intervals of the relative similarity coefficient values and the corresponding degrees of similarity [46].

Table 1. The intervals of the relative similarity coefficient $(R S C)$ values and the corresponding degrees of similarity.

\begin{tabular}{cccccc}
\hline $\begin{array}{c}\text { Degree of } \\
\text { Similarity }\end{array}$ & $\begin{array}{c}\text { Very Low } \\
\text { Similarity }\end{array}$ & Low Similarity & $\begin{array}{c}\text { Average } \\
\text { Similarity }\end{array}$ & High Similarity & $\begin{array}{c}\text { Very High } \\
\text { Similarity }\end{array}$ \\
\hline$R S C\left(w_{t}, w_{s}\right)$ & {$[0 ; 0.20)$} & {$[0.20 ; 0.40)$} & {$[0.40 ; 0.60)$} & {$[0.60 ; 0.80)$} & {$[0.80 ; 1.00)$} \\
\hline
\end{tabular}

Source: Authors' own elaboration based on [46].

In order to answer research question RQ4 and verify research hypothesis RH4 a synthetic measure was constructed, which was used to assess the respondents' sense of social insecurity. This process was based on the fuzzy TOPSIS method (Technique for Order of Preference by Similarity to Ideal Solution) [47], which consisted of three main stages:

Stage 1. Creation of a hierarchical structure concerning the sense of social insecurity. Stage 2. Normalisation and aggregation of the variable values.

Stage 3. Linear ordering and typological classification of objects according to the synthetic measure value.

Stage 1. The hierarchical structure of the multiple-criteria problem of the sense of social insecurity was created by breaking it down into the following elements: the main evaluation criterion (i.e., the sense of social insecurity) and subordinate criteria (the sense of insecurity of the future socioeconomic situation of one's household and the sense of insecurity of the future socioeconomic situation in Poland), variables $\left(V_{1}-V_{7}\right)$ (Figure 1). The main criterion was placed at the top of the hierarchy and consisted of two subordinate criteria. These included several qualitative variables describing the households surveyed.

Each linguistic variable was assessed according to a five-point scale, where: 1-definitely not, 2-no, 3-maybe, 4-yes, 5-definitely yes. Next, the variants of household responses to each variable were compiled into two data matrices $X_{C_{j}}=\left[x_{i k}\right],(j=1,2)$, where: $x_{i k}\left(i=1,2, \ldots, m ; k=1,2, \ldots, p_{j}\right)$ 一opinion (qualitative variable variant) of the $i$-th household about the $k$-th variable; $m=3 n$, where $n$ was the number of households surveyed at each of the three stages, $p_{j}$-number of variables within criterion $j(j=1,2) ; p_{1}=4$ and $p_{2}=3$. Each household was assessed according to two subordinate criteria $C_{j}(j=1,2)$ and $p_{j}$ of the variables adopted for their description. 


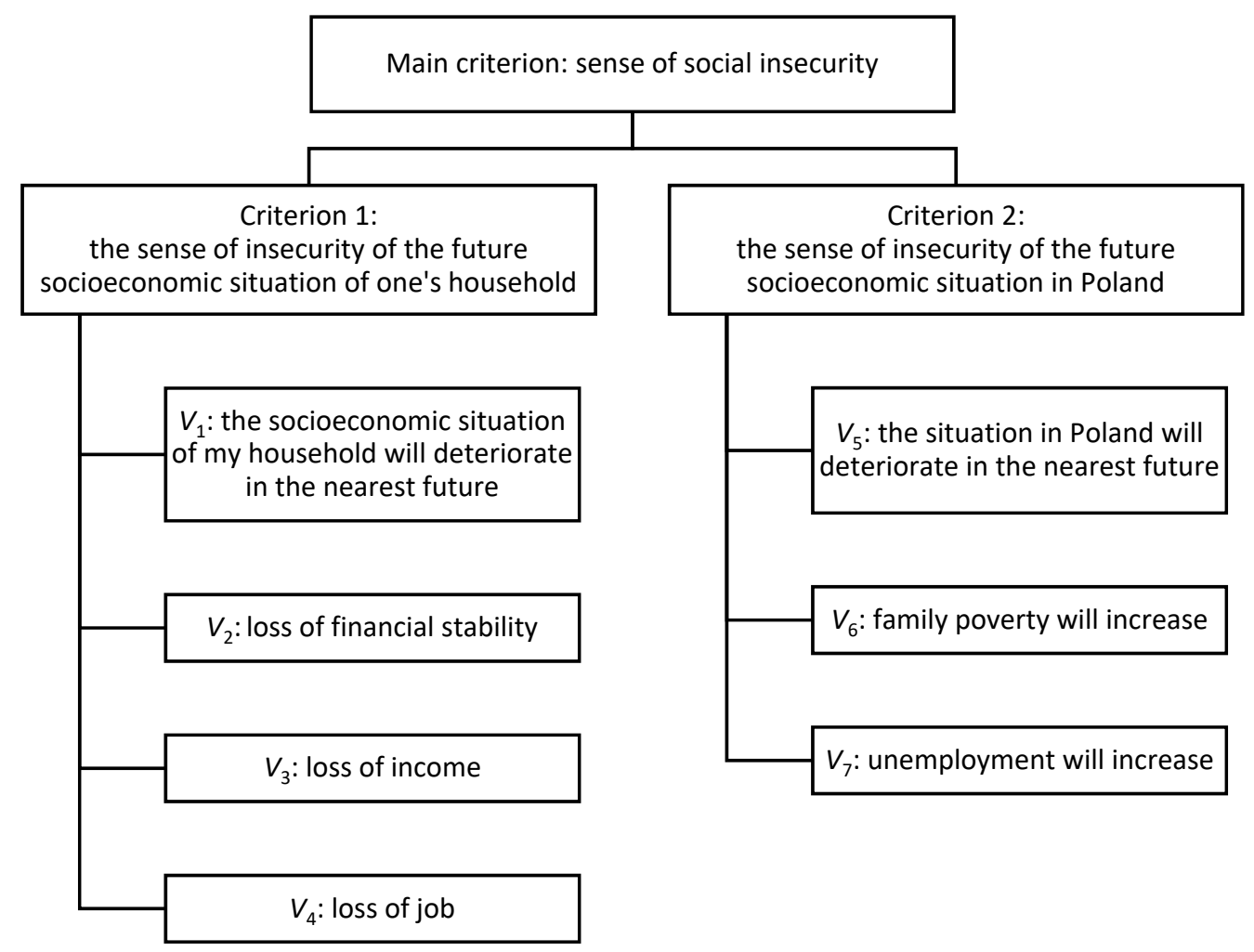

Figure 1. The hierarchical structure of the sense of social insecurity. Source: Authors' own elaboration.

The variants of household responses obtained were transformed into triangular fuzzy numbers. On the ordinal scale, the arithmetic operations can be performed, and due to the fact that the distance between the numbers is not specified, we used fuzzy numbers to solve this problem. Table 2 shows the method of changing a linguistic variable with five levels, each expressed by a fuzzy triangular number $\widetilde{x}=(a, b, c)$ in the form of three parameters. For example, the respondents assessed, e.g., whether the socioeconomic situation of their own household will deteriorate in the nearest future $\left(V_{1}\right)$. If one of the respondents expressed concern about the deterioration of their own household in socioeconomic situation as "definitely yes", this corresponds to 5 on the ordinal scale. Then, 5 is converted to a triangular fuzzy number as $(80,100,100)$. However, if another respondent assessed that the socioeconomic situation of own household will not deteriorate in the nearest future, and answered "no", this corresponds to the number 2 on the ordinal scale. Then, 2 is transformed into a triangular fuzzy number as $(20,30,40)$. Thanks to these transformations, all relations between the fuzzy numbers were shown as operations on their parameters $[48,49]$.

Table 2. The linguistic variable levels and the corresponding triangular fuzzy number used to describe the ordinal variables.

\begin{tabular}{|c|c|c|c|c|c|}
\hline Linguistic Variable Level & Definitely Not & No & Maybe & Yes & Definitely Yes \\
\hline Five-point scale & 1 & 2 & 3 & 4 & 5 \\
\hline Triangular fuzzy numbers $(a, b, c)$ & $(0,0,20)$ & $(20,30,40)$ & $(40,50,60)$ & $(60,70,80)$ & $(80,100,100)$ \\
\hline
\end{tabular}

Source: Authors' own elaboration based on [50].

The triangular fuzzy numbers corresponding to the qualitative variable variants were compiled as fuzzy data matrices $\widetilde{\boldsymbol{X}}_{C_{j}}=\left[\widetilde{\boldsymbol{x}}_{i k}\right],(j=1,2)$, where $\widetilde{\boldsymbol{x}}_{i k}=\left(a_{i k}, b_{i k}, c_{i k}\right)$, $i=1,2, \ldots, m, k=1, \ldots, p_{j}, p_{j}$-the number of variables for subordinate criterion $C_{j}$ $(j=1,2), m$-the number of objects. In our study $p_{1}=4$, and $p_{2}=3$. 
At the second stage the values of the variables should be normalised in order to make them comparable. Different variables (i.e., benefit and cost) should be normalised according to the selected formula $[47,51,52]$. All variables in this study were defined on the same scale and they were benefit variables. Thus, normalisation was not required.

The values of the variables were multiplied by weight factors relating to the importance of the variables in each subordinate criterion:

$$
\widetilde{\boldsymbol{r}}_{i k}=\widetilde{\boldsymbol{x}}_{i k} w_{k}\left(i=1,2, \ldots, m ; k=1, \ldots, p_{j}\right)
$$

where $\widetilde{r}_{i k}=\left(l_{i k}, m_{i k}, u_{i k}\right)$. The same weights were assumed for the variables.

Next, the coordinates of model objects were determined-the positive ideal solution (PIS) ${\widetilde{A_{j}}}^{+}$and the negative ideal solution (NIS) ${\widetilde{A_{j}}}^{-}$for each subordinate criterion $(j=1,2)$.

$$
\begin{aligned}
& {\widetilde{\boldsymbol{A}_{j}}}^{+}=\left(\max _{i}\left(\widetilde{\boldsymbol{r}}_{i 1}\right), \max _{i}\left(\widetilde{\boldsymbol{r}}_{i 2}\right), \ldots, \max _{i}\left(\widetilde{\boldsymbol{r}}_{i p_{j}}\right)\right)=\left(\widetilde{\boldsymbol{r}}_{1}^{+}, \widetilde{\boldsymbol{r}}_{2}^{+}, \ldots, \widetilde{\boldsymbol{r}}_{p_{j}}^{+}\right) \\
& {\widetilde{\boldsymbol{A}_{j}}}^{-}=\left(\min _{i}\left(\widetilde{\boldsymbol{r}}_{i 1}\right), \min _{i}\left(\widetilde{\boldsymbol{r}}_{i 2}\right), \ldots, \min _{i}\left(\widetilde{\boldsymbol{r}}_{i p_{j}}\right)\right)=\left(\widetilde{\boldsymbol{r}}_{1}^{-}, \widetilde{\boldsymbol{r}}_{2}^{-}, \ldots, \widetilde{\boldsymbol{r}}_{p_{j}}^{-}\right)
\end{aligned}
$$

where $\widetilde{\boldsymbol{r}}_{k j}^{+}=\left(l_{k j}^{+}, m_{k j}^{+}, u_{k j}^{+}\right), \widetilde{\boldsymbol{r}}_{k j}^{-}=\left(l_{k j}^{-}, m_{k j}^{-}, u_{k j}^{-}\right)$.

This was the basis for the calculation of distances for each object assessed from PIS $d_{i j}^{+}$ and NIS $d_{i j}^{-}$:

$$
\begin{aligned}
& d_{i j}^{+}=\sum_{k=1}^{p_{j}} \sqrt{\frac{1}{3}\left[\left(l_{i k}-l_{k j}^{+}\right)^{2}+\left(m_{i k}-m_{k j}^{+}\right)^{2}+\left(u_{i k}-u_{k j}^{+}\right)^{2}\right]}(i=1,2, \ldots, m ; j=1,2), \\
& d_{i j}^{-}=\sum_{k=1}^{p_{j}} \sqrt{\frac{1}{3}\left[\left(l_{i k}-l_{k j}^{-}\right)^{2}+\left(m_{i k}-m_{k j}^{-}\right)^{2}+\left(u_{i k}-u_{k j}^{-}\right)^{2}\right]}(i=1,2, \ldots, m ; j=1,2) .
\end{aligned}
$$

Next, the values of synthetic measures were calculated for the sense of insecurity of the future of one's household and the sense of insecurity of the future situation in Poland by means of the following formula:

$$
S_{i j}=\frac{d_{i j}^{-}}{d_{i j}^{+}+d_{i j}^{-}}(i=1,2, \ldots, m ; j=1,2) .
$$

The $S_{i j}$ values were normalised to the interval $(0,1)$ so that $S_{i j}$ assumed the value of 0 for the anti-model object (NIS) and the value of 1 for the model object (PIS). The smaller the distance of a household from the positive ideal solution, and thus the greater the distance from the negative ideal solution, the closer was the value of the synthetic measure to 1 .

The third stage involved the identification of the level of social insecurity in one's household and in Poland as a whole on the basis of the normalised $S_{i j}$ values, according to the research stages. For this purpose, the values were averaged using the median for Poland, as well as for the rural areas and different categories of urban areas. Next, the types of the sense of social insecurity were distinguished arbitrarily, assuming the numerical intervals of the synthetic measure values $S_{i j}$ as shown in Table 3.

Table 3. The levels of the sense of social insecurity and the corresponding intervals of the synthetic measure values.

\begin{tabular}{cccccc}
\hline Level & Very Low & Low & Medium & High & Very High \\
\hline$S_{i j}$ & {$[0.00 ; 0.20)$} & {$[0.20 ; 0.40)$} & {$[0.40 ; 0.60)$} & {$[0.60 ; 0.80)$} & {$[0.80 ; 1.00)$} \\
\hline Source: Authors' own elaboration based on [53].
\end{tabular}




\section{Results}

\subsection{Subjective Assessment of Social Security of Households during the COVID-19 Pandemic}

Security is one of the most important values for every person and country. It can be considered according to various criteria, the main ones being the objective, subjective or spatial approach. In the objective approach, security may concern individuals, social groups, countries, or international security. In the subjective approach, security is presented within its areas of concern (e.g., social, economic, political security). Moreover, security can be considered according to the place of occurrence (e.g., global, local security). The significance of security has changed over the centuries, and it can be defined in different ways. A narrow definition of security concerns its military concept and the defence of sovereign interests of the state. However, our considerations are concentrated on security in its broader sense, i.e., social security. Social security can be defined as the perception of "all the ways in which people organise their lives in order to ensure access to an adequate income" [54]. According to Webb and Wills-Herrera [55], the subjective sense of security or insecurity is one of the main dimensions affecting development and well-being. Currently, it is still valid to say that "contemporary thinking about security should include the many interactions between the social, political, cultural, epidemiological, and economical systems, which are often studied and treated separately in past research" [56]. In the context of our research, the following definition of the concept of a sense of social security should therefore be proposed: a subjective feeling that the material needs of the household are satisfied and one is able to acquire funds to maintain at least the current standard of living in the household.

This study presents the respondents' feelings concerning the social security of their households and their perception of the security of the future situation in Poland expressed at three stages of the research. The respondents expressed their sense of insecurity about the future of their households, including their subjective feelings about the deterioration of the situation of their households in the near future, the loss of financial stability, income, and jobs. The respondents' feelings about the situation of their households were compared with their sense of insecurity about the future situation in Poland. The respondents assessed the possible deterioration of the situation in Poland in the near future, an increase in unemployment and poverty in families. The comparison of the respondents' feelings about the possible deterioration of the situation of their households and the situation in Poland revealed a dichotomy. At the first stage of the research almost $84 \%$ of the respondents (answers: yes and definitely yes) assumed that the situation in Poland would deteriorate, $60 \%$ of whom were sure of it (Figure 2 ).

At the second stage, almost $69 \%$ of the respondents expressed their concern about the deterioration of their situation, and $39 \%$ of them were definitely sure of this. At the third stage, this fraction decreased slightly to about $68 \%$, but the number of people who were certain that their situation would deteriorate increased by more than 5 percentage points. However, the same respondents did not assess their own situation so strictly. At the first stage, almost $23 \%$ of the respondents were certain that their situation would worsen, and slightly less than $25 \%$ of the respondents believed that this was probable. At the second stage, these percentages decreased by about 12 and 7 percentage points, respectively, and remained at a similar level at the third stage (Figure 2). The value of the RSC index was 0.87 . It showed that the structures of the responses given at the second and third stages were highly consistent (Figure 3). However, it is noteworthy that the structures of the responses concerning the assessment of the situation of the respondents' households and the situation in Poland exhibited only medium similarity (the RSC was about 0.45 ). 


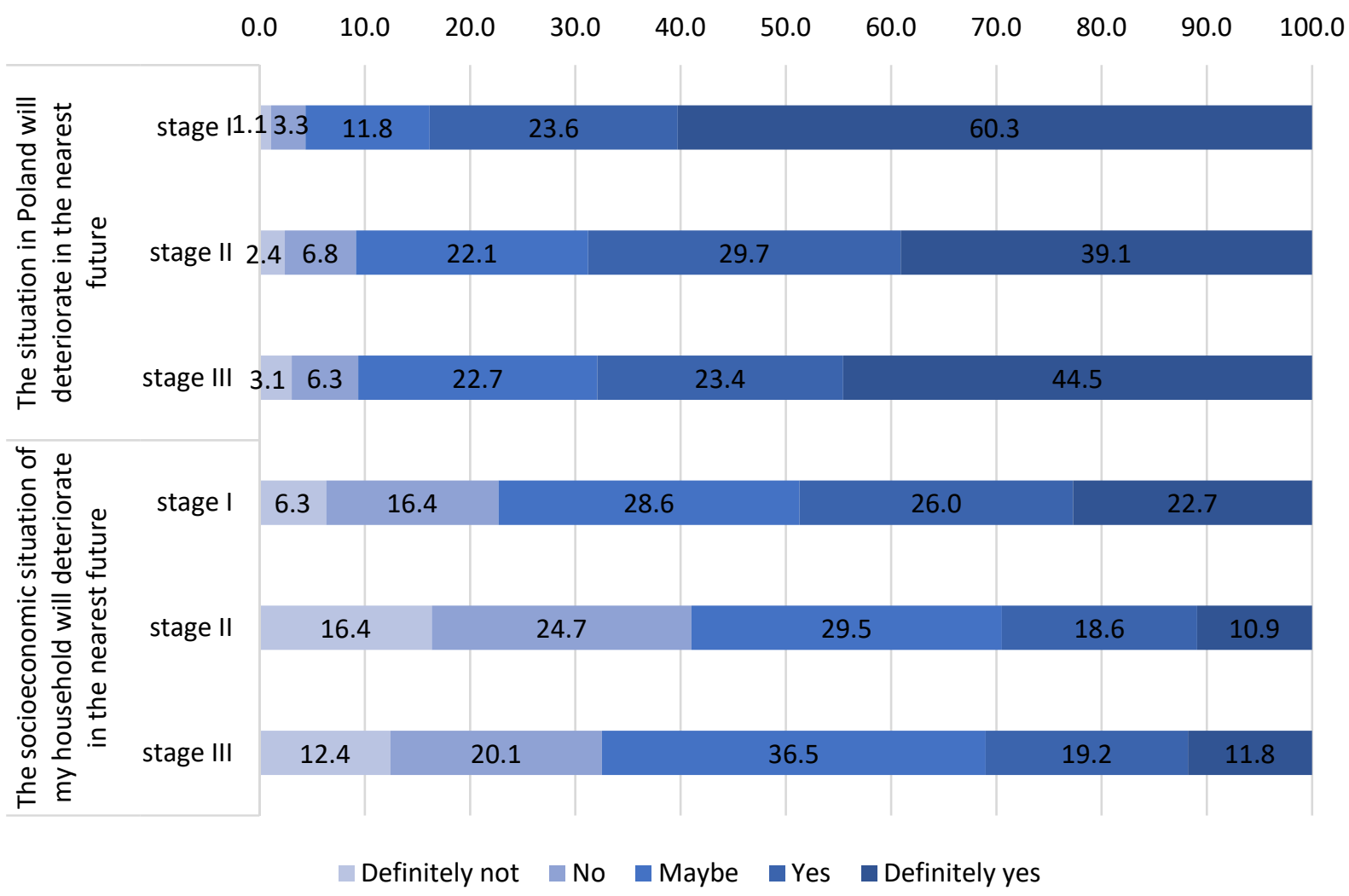

Figure 2. The respondents' perceptions of changes in the situation in Poland and their households (\%). Source: Authors' own elaboration based on [44].
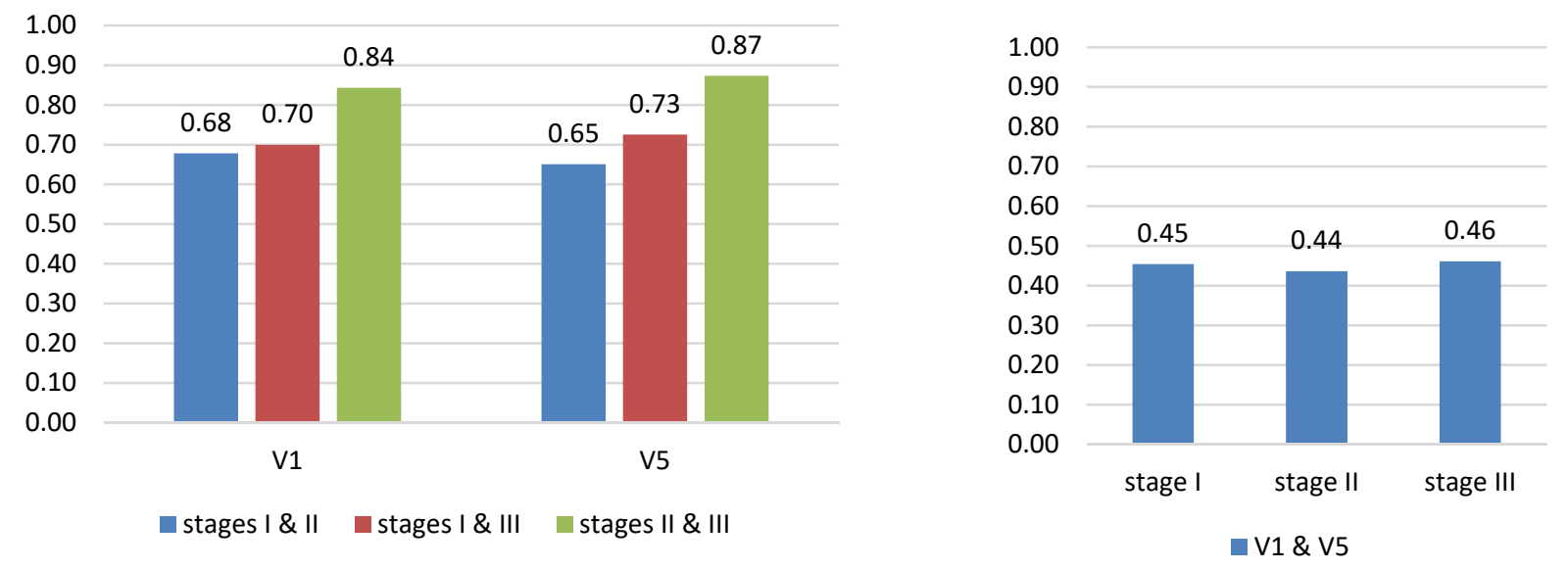

Figure 3. Values of the RSC index showing the degrees of similarity between the research stages and variables in relation to the respondents' perceptions of changes in the situation their households and the situation in Poland. Note: $V_{1}$ : the socioeconomic situation of my household will deteriorate in the nearest future, $V_{5}$ : the situation in Poland will deteriorate in the nearest future. Source: Authors' own elaboration based on [44].

The feeling that the effects of the pandemic and the economic lockdown did not directly affect the respondents increased their optimism. The respondents' perception was also influenced by the fact that they had become used to the coronavirus pandemic restrictions and returned to their everyday tasks. The lockdown ended in most areas of the respondents' personal lives and their jobs, thus their sense of insecurity decreased. Returning to work, the possibility of participating in cultural events, and lower restrictions reduced the respondents' interest in the survey. It is noteworthy that the third stage was completed just before the introduction of further restrictions in the Polish economy. If the 
survey had been conducted at a slightly later date, the answers provided by the respondents might have changed significantly and their pessimism may have increased.

The Wilcoxon test showed that the $p$-value was below the significance level (0.05). At each stage of the research, there was a statistically significant difference in the respondents' level of perception of the deterioration of the situation of their households and the situation in Poland. These differences consisted in the fact that the respondents' subjective sense of deterioration of the situation of their households was lower (median 3 at each stage of the research) than their sense of deterioration of the situation in Poland (median 5-stage I, median 4-stage II and III).

The respondents were pessimistic as they expected the level of poverty in Poland to increase. At the first stage of the research, about $84 \%$ of the respondents (answers: yes and definitely yes) assumed that the situation in Poland would deteriorate, and almost $59 \%$ of them were sure of this (Figure 4). At the second stage, the negative perception decreased by over 16 percentage points, whereas at the third stage the change amounted to 2 percentage points only (from $67.5 \%$ in June 2020 to $65.3 \%$ in September 2020). It is noteworthy that at the second and third stages of the research, the respondents' perception of the increasing level of poverty in Poland was characterised by very high consistency, as evidenced by the value of the RSC index equals 0.94 (Figure 5). Far fewer people were concerned about their financial situation. Here, the changes between the first and second stage were greater and the respondents were more optimistic. The percentage of the respondents who were worried about losing financial stability fell from $39.7 \%$ at stage I to $23.8 \%$ at stage II. However, at stage III it increased slightly to $27.5 \%$. It is noteworthy that the percentage of the respondents who were definitely worried about losing financial stability dropped by almost half at the second and third stages of the research (from 20.5\% to $10.9 \%$ and $10.0 \%$ ) (Figure 5).

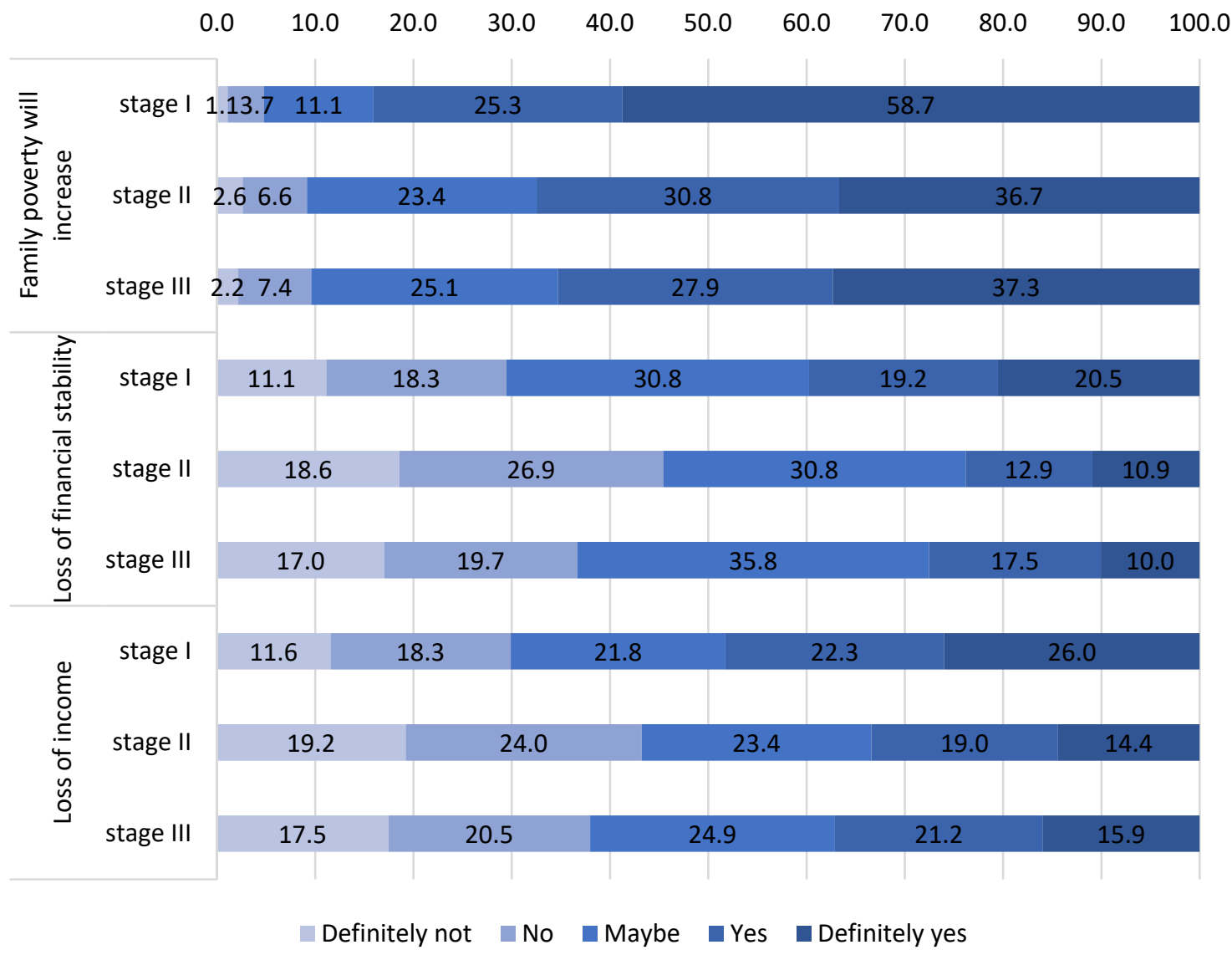

Figure 4. The respondents' perceptions of increase in the poverty of their households and the loss of financial stability and income (\%). Source: Authors' own elaboration based on [44]. 

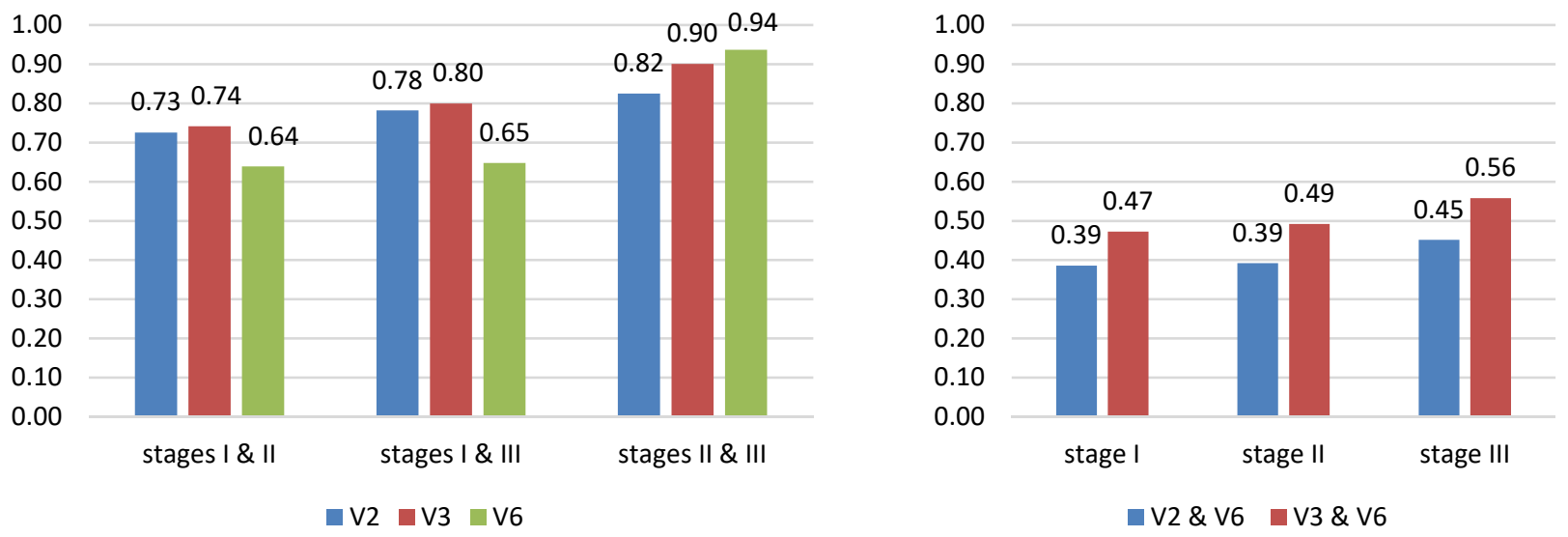

Figure 5. Values of the RSC index showing the degrees of similarity between the research stages and variables in relation to the respondents' perceptions of increase in the poverty of their households, loss of financial stability, and income. Note: $V_{2}$ : loss of financial stability, $V_{3}$ : loss of income, $V_{6}$ : family poverty will increase. Source: Authors' own elaboration based on [44].

The respondents' perception of the loss of income was slightly higher. At stage I, $48.3 \%$ of the respondents assumed that the situation of their households would deteriorate, and almost $26 \%$ of them were sure of this. At stage II, this percentage decreased to $33.4 \%$, whereas at stage III the situation was slightly worse (37.1\%). It is noteworthy that at the second and third stages of the research, the respondents' perception of the loss of financial stability and income was characterised by very high consistency (the values of the RSC index were greater than 0.8, Figure 5).

The analysis of the results of the Wilcoxon test showed $p<0.05$ for all stages. This means that at each stage of the research, there was a statistically significant difference in the respondents' perceptions of the increase in the poverty of families in Poland, the loss of their financial stability, and the possible loss of income. The medians of the respondents' ratings referring to their perception of the loss of the financial stability of their households (median 3 at each stage of the research) and loss of income (the medians were equal to 3 at each stage of the research) were lower than the median referring to their perception of the increase in the poverty of families (median 5-stage I, median 4-stages II and III).

The question about the possible loss of employment also confirmed the divergence in the respondents' perceptions. There was a noticeable difference between the percentage of the respondents who were afraid that unemployment would increase in Poland and those who felt that they would lose their job. In April 2020, 70.4\% of the respondents were convinced that unemployment would increase. In June 2020 this percentage dropped by 27 percentage points, whereas in September 2020 it decreased by another 3 percentage points. In September 2020 (the third stage of the research), 72.9\% of the respondents (a decrease by 18.8 percentage points in comparison with the first stage and by 7 percentage points in comparison with the second stage) expressed their concern (answers: definitely yes and yes) about increasing unemployment in Poland. The respondents' assessment of the increase in unemployment was characterised by very high consistency, as evidenced by the values of the RSC index showing the degrees of similarity between the stages of the research $(R S C>0.8)$. It is noteworthy that in September 2020, only $10.9 \%$ of the respondents were sure they would lose their jobs, and another $11.4 \%$ expressed such concern. At the same time, during the last period of the survey, when the incidence of the disease began to increase significantly, the respondents' fear of losing their jobs increased only slightly between the second and third stages of the research (Figure 6). Detailed analysis showed that the concern about the job loss was chiefly expressed by the respondents whose employment contracts were about to expire, those running their own businesses, and those who had lost financial liquidity as a result of the lockdown. It is likely that the restrictions introduced in October, i.e., just after the survey, would have intensified the respondents' concerns. Additional questions addressed to some of the respondents lead to the conclusion 
that their fear of the loss of employment increased again at the end of October 2020. One of the respondents running a restaurant said he could not stand another lockdown. Another said it would ruin his business. A respondent working in a theatre said that a smaller audience meant a lower pay not only for the actors but also for other staff, who might be laid off. It is also noteworthy that the respondents' negative feelings expressed in their answers to the additional questions they were asked in October 2020 could have been influenced by other events in Poland [21].

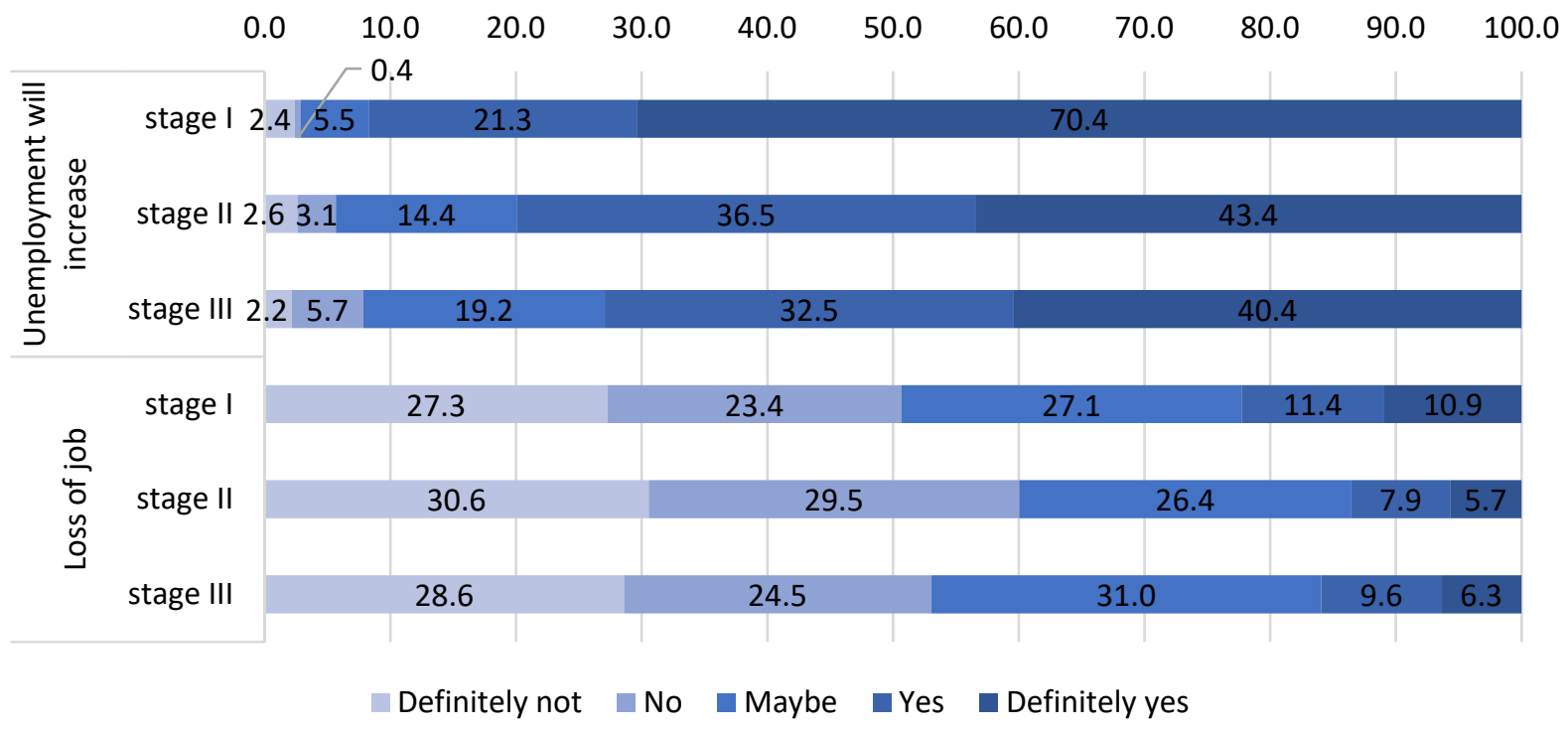

Figure 6. The respondents' perceptions of the increase in unemployment and job loss (\%). Source: Authors' own elaboration based on [44].

It is noteworthy that the respondents' opinions were characterised by the greatest dichotomy in their perception of losing their job and an increase in unemployment in Poland. The values of the RSC index showing structural similarity of the responses to these variables were low or very low at each stage of the research (Figure 7). Moreover, there were statistically significant differences in the respondents' level of fears of job loss and an increase in unemployment in Poland. These differences were demonstrated in the Wilcoxon test $(p<\alpha=0.05)$. These differences consisted in the fact that the respondents' subjective fear of the loss of their job was lower (median 2 at each stage of the research) than their fear of the increase in unemployment in Poland (median 5-stage I, median 4-stages II and III).
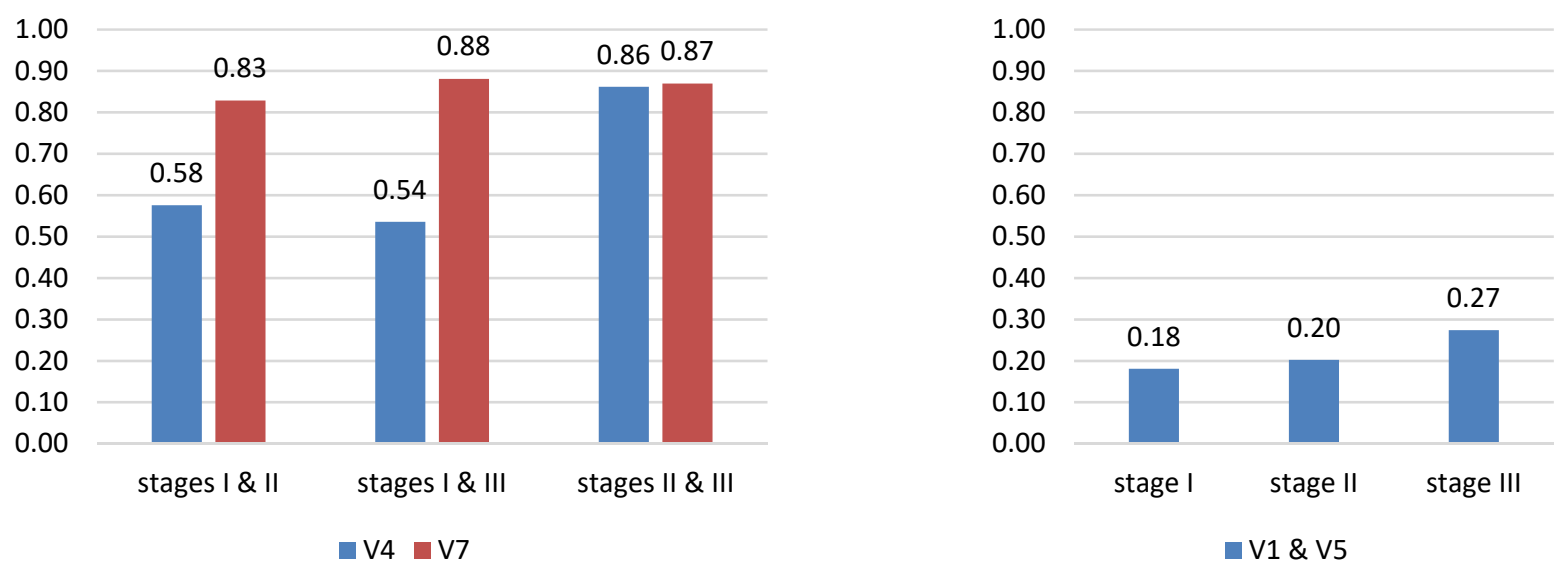

Figure 7. Values of the RSC index showing the degrees of similarity between the research stages and variables in relation to the respondents' perceptions of job loss and an increase in unemployment. Note: $V_{4}$ : loss of my job, $V_{7}$ : unemployment will increase. Source: Authors' own elaboration based on [44]. 
The analysis of the graphic profile of rural and urban respondents' perceptions of the situation of their households and the situation in Poland showed that the ratings at the first stage of the research were definitely worse than at the subsequent stages. Additionally, the dichotomy between the respondents' perceptions concerning the individual and macroscale situations was confirmed. It is noteworthy that at the third stage, the impact of the epidemic in rural areas was noticeable. Rural respondents perceived their financial situation worse than the city inhabitants. The analysis also confirmed earlier theses that the rural respondents' perception of unemployment was more favourable than the city inhabitants' perception (Figure 8).

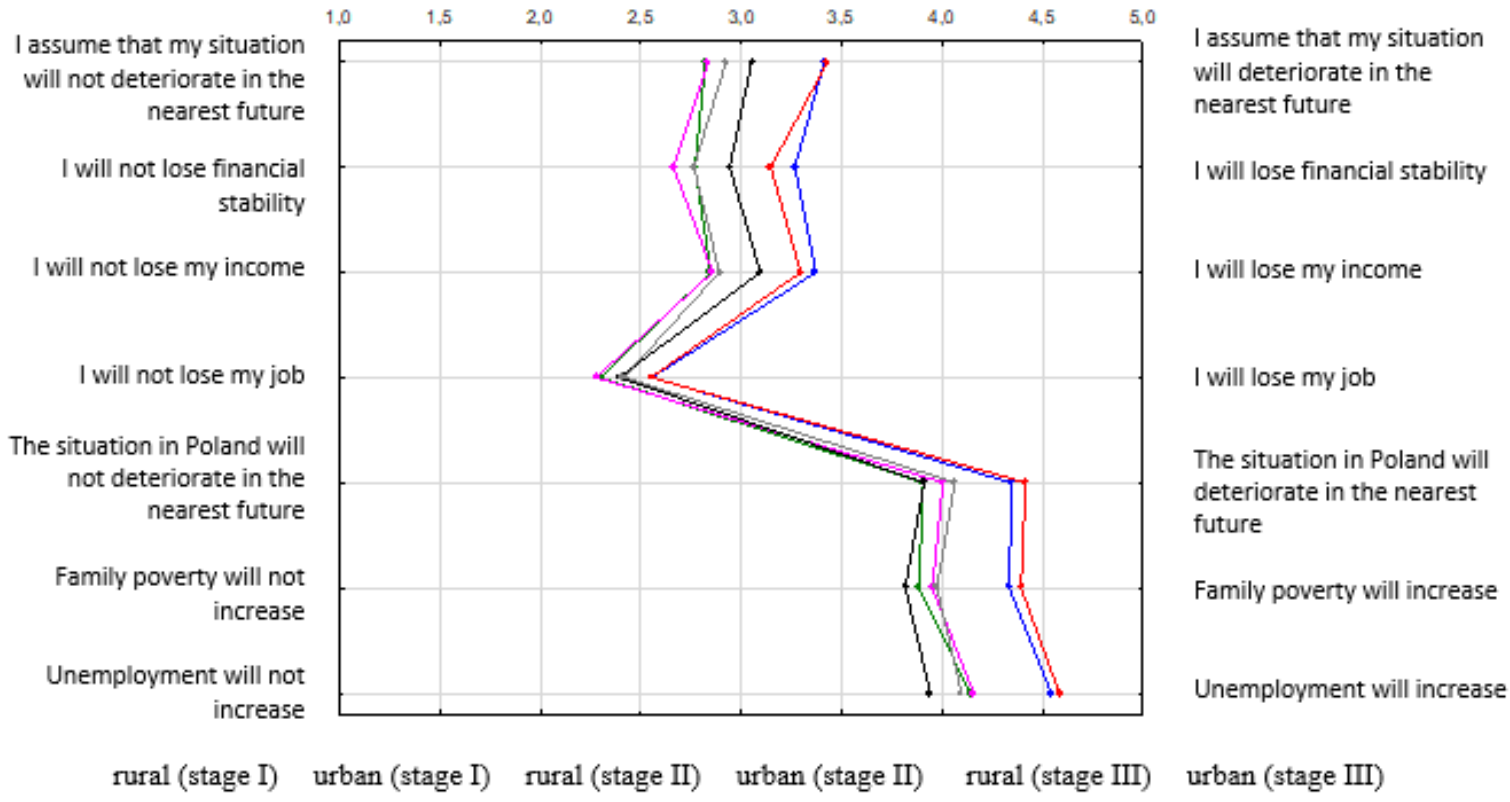

Figure 8. A graphic profile of rural and urban respondents' perceptions of the future situation of their households and the situation in Poland (stages I-III). Source: Authors' own elaboration based on $[44,56]$.

In order to confirm the analyses presented above, box and whisker plots based on descriptive statistics were prepared for all stages of the research, with the median as the central point. Detailed analysis of Figure 9 shows a shift in the median of responses between stage I and stage II as well as slight shifts in the upper and lower quartiles. This indicates that the respondents' optimism increased. The lower the values of the positional measures, the better was the respondents' assessment of their current situation and the situation in Poland. Apart from this, the comparison of the $p$ values in the Wilcoxon test with the significance level of $\alpha=0.05$ showed that at each stage of the research, there were no statistically significant differences in the respondents' perceptions between the fact that the situation in Poland would become worse and that poverty in families would increase (stage I: $p=0.607$, stage II: $p=0.452$, stage III: $p=0.488$ ), and between their perceptions of the deterioration of the situation of their households and the loss of income (stage I: $p=0.072$, stage II: $p=0.662$, stage III: $p=0.849$ ).

\subsection{Subjective Assessment of the Level of Social Insecurity Concerning the Future Situation of} One's Household and the Situation in Poland

Synthetic measures were also used to assess the respondents' level of insecurity about the future situation of their households and the situation in Poland, including the division into rural and urban areas (Figure 10). The level of the sense of social insecurity concerning one's household is defined as the degree of one's subjective feeling of being threatened by poverty and a lower standard of living caused mainly by social risk, e.g., illness, unemployment, poverty, or other random events. The variables shown in Figure 1 were 
adopted. They were based on the research survey My Situation During the Coronavirus Pandemic [44]. The FuzzyMCDM package was used for calculations [57] in R [58].

situation of household

situation in Poland

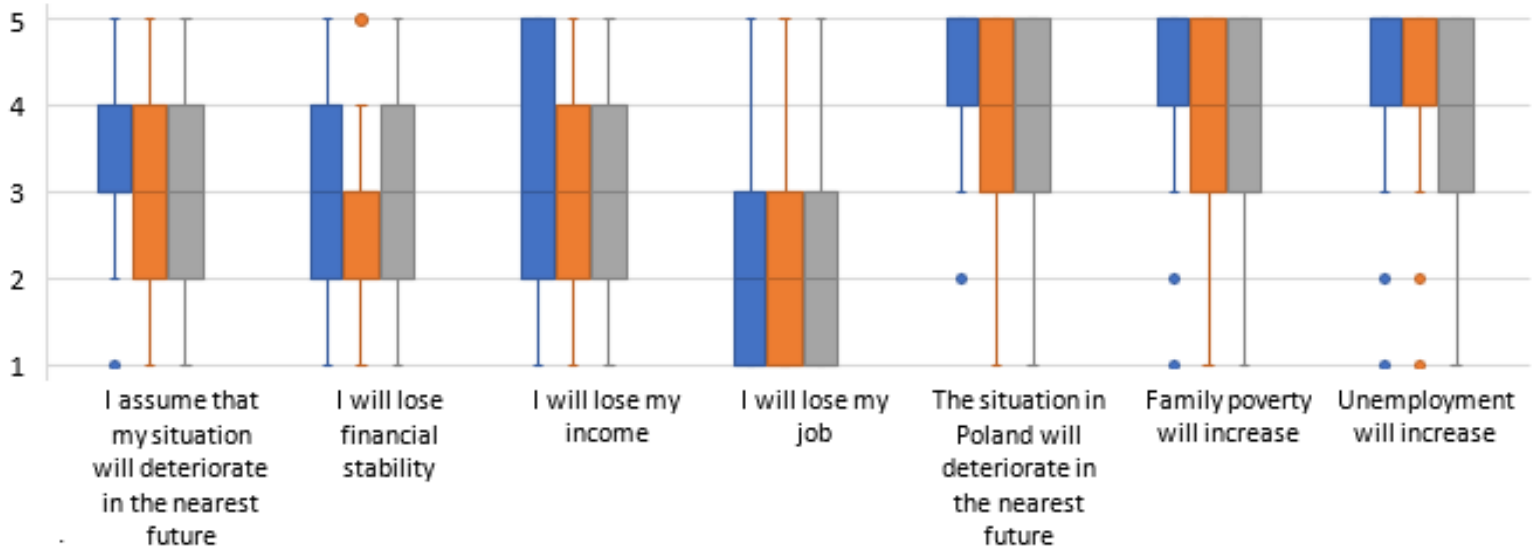

stage I $\square$ stage II $\square$ stage III

Figure 9. A box plot of the respondents' perceptions of the future situation of their households and their opinions on the future situation in Poland (stages I-III). Source: Authors' own elaboration based on [44].

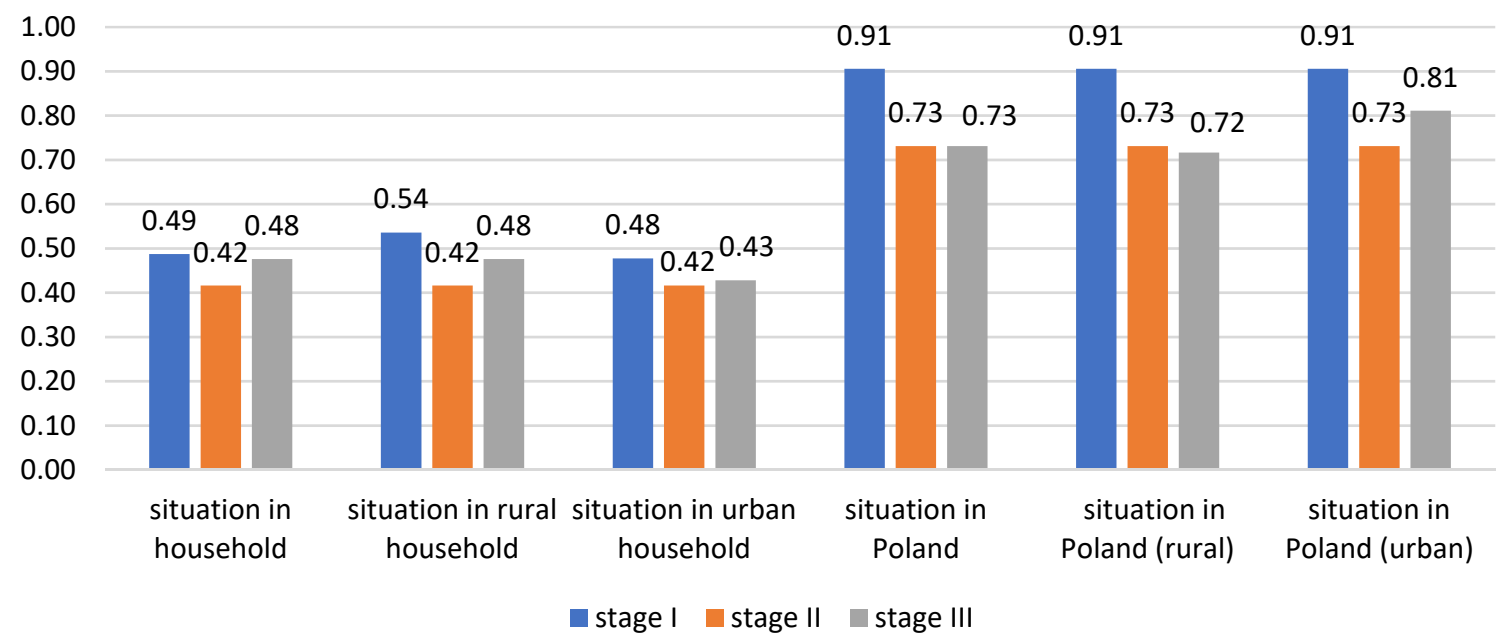

Figure 10. Values of the synthetic measure of the level of sense of social insecurity. Note: The values of synthetic measures were calculated as medians for the corresponding groups of households. Source: Authors' own elaboration based on [44].

The analysis of Figure 10 reveals a noticeable dichotomy between the respondents perceptions of the future situation of their households and the situation in Poland. At each stage of the research, the respondents' perceptions of the situation of their households were much more optimistic, as evidenced by the medium level of the values of synthetic measures. However, it is noteworthy that at the first stage of the research, the rural respondents' level of perception of the possible deterioration of the situation of their households (synthetic measure value 0.54 ) was slightly higher than the level of perception of the city inhabitants (0.48). Moreover, at the second stage of the research, the value of the synthetic measure was slightly lower than at the first stage, but it increased again at the third stage.

The analysis of the respondents' perceptions of the situation in Poland showed that at the first stage of the research they were very pessimistic in the perception of social insecurity. The value of the synthetic measure was 0.91 . The respondents' perceptions 
became more positive at the subsequent stages of the research. However, it is noteworthy that at the third stage of the research urban inhabitants felt more pessimistic about the possible deterioration of the situation in Poland. This was reflected by the average value of the synthetic measure, which was 0.81 for urban residents, and 0.72 for rural inhabitants. This means that urban residents were affected by the coronavirus pandemic more than rural inhabitants.

\section{Discussion}

It is intriguing why there was a dichotomy in the respondents' perceptions. If there is general prosperity and the economic situation is good, people have higher aspirations. Richer people may therefore perceive their standard of living as being worse. However, at the time of crisis or special situations, such as a pandemic, people may have a completely different approach. When respondents compare themselves with other reference groups, they may feel that their situation is better, thus they find it easier to accept their current standard of living. As they have limited possibilities to achieve their goals, they lower their aspirations and accept their economic situation. Moreover, at the initial period of the pandemic there may have been a "bolt effect" - people maintained their current standard of living although they lost some income. At the second and third stages of the research the respondents noticed that, in most cases, their situation had changed minimally. As a result, their ratings improved and their optimism increased. In the survey, they also expressed the opinion that the pandemic did not directly affect them and their surroundings, but it affected other people. It is likely that the sudden increase in the incidence of the COVID-19 disease in October and November 2020 would have changed the respondents' perception of their situation. A higher risk of the disease and its increasing incidence in the respondents immediate environment would have resulted in a larger number of negative assessments.

Although initially it seemed that the dichotomy in the respondents' feelings would gradually disappear as the risk of the loss of job and income approached or faded away, our observations showed that this dichotomy in assessments continued. At the second and third stages of the research, two phenomena caused improvement in the respondents' ratings of the situation - they became used to the coronavirus pandemic, and they felt that the authorities had taken exaggerated measures to control the situation. At the initial period of the research, the respondents were concerned about the situation in Poland and their households. Their concerns about the situation in Poland were influenced by the media, which fuelled the atmosphere of insecurity, and by the restrictions introduced after 20 March 2020. A detailed assessment of the epidemiological situation in Poland and other European countries in the first months of the pandemic was shown in the study by Łuczak and Kalinowski [59]. According to Holman et al. [60] and van den Bulck and Custers [61], the involvement of the media in various traumas increases people's anxiety and stress. The level of insecurity increased along with the information provided by the media, including social networking sites. TV journalists used metaphors which evoked the feeling of fighting a war ("doctors and nurses on the frontline") and resulted in the respondents' lower ratings of the current situation. The language of war, full of catastrophism and apocalyptic comparisons intensified the sense of fear. In media reports, COVID-19 became a "posthuman creature" with a great sense of agency, almost like in works by Bruno Latour [62]. However, as time passed and people returned to reality, there were voices denying the pandemic and actions showing that people had become accustomed to it, which caused a change in their emotional patterns. As the immediate danger weakened, people felt less threatened in their personal lives and at work. There were therefore higher ratings at the second stage of the research, when the situation began to return to normality. Although some people, including owners of enterprises, still did not know how their situation would develop, the slow return to the pre-pandemic situation noticeably improved their ratings. At the third stage, when the situation had begun to return to normality, the respondents' ratings remained at the same level, although many of 
them were still uncertain of their future. Some entrepreneurs began to regain their clients, and there was a chance to make up for at least some of the losses from the previous months.

The next stages of the pandemic were characterised by "new normality", which was manifested by a change in some people's aspirations. Kahneman [63] and van Praag and Frijters [64] extensively discussed the adaptation to expectations in their studies. The adaptation changed people's expectations. The satisfaction of one's needs at a high, often hedonistic level was reduced to a limited level. Moreover, this lower level became obvious to some people. Michoń [65] expressed his apprehension of such a simple adaptation, which may lead to the feeling that one can do little by oneself and that every action seems to be pointless. However, the researcher expressed his fears at a time when hardly anybody was thinking of a pandemic, and the satisfaction of one's needs depended mainly on the purchasing power of one's income. Should the same concerns be expressed during the pandemic? The answer to this question depends on whether the adaptation is temporary or permanent and whether vaccines and the partial or total elimination of the coronavirus will result in the development of "even newer normality".

The perception of the situation in one's environment may be influenced by the fact that under the circumstances of ambiguity or even uncertainty people tend to attach more importance to negative information provided by the media. In consequence, the respondents' optimism may be weakened on a macro scale [66]. The respondents' assessment of their situation improved as they were becoming accustomed to the unusual situation. The higher ratings of their situation may be explained by the self-valorisation theory, i.e., the pursuit to raise one's self-esteem [67]. This consists in processing information from the environment (including TV programmes about COVID-19) and comparing it with one's personal situation. In this way, one's personal situation seems to be positive, whereas the information obtained from the media weakens the assessment of one's environment.

The sense of insecurity, and consequently the assessment of one's situation, is influenced by a number of economic factors, such as changes in prices, the value of money, continuity of employment and one's income, the amount of one's real savings, the continuity of public services, etc. [68]. However, their strength depends on the simultaneous influence of the social consequences of a particular phenomenon, including personal interests and behavioural characteristics of individuals. The accumulation of these factors causes states of deviation from the normal situation, and results in an intensified or weakened assessment of it. It is noteworthy that the assessment of these factors may be biased. According to Daniel Kahneman [63], people tend to be irrational in a narrow constructivist context when they feel insecure. The social and behavioural aspects thus influence cognitive errors. The dichotomy in perceptions may therefore be the result of cognitive errors [69].

It is also important to consider the initial situation of the respondents in relation to the reference groups. When living conditions are generally deteriorating, a comparable or even slightly lower level of satisfaction of one's needs may favour the reduction of these needs and, consequently, it may lead to greater acceptance of one's level of consumption. A compensatory mechanism appears, which economic psychology refers to as "sweet lemons". This is manifested by the acceptance of goods which were previously regarded with aversion. This individual rationality is a self-conscious process of maximisation of one's assessment. In consequence, another question arises, of whether one's individual situation or the situation of one's household is so much different from the situation of one's environment.

It is noteworthy that the dichotomy in perceptions of poverty results from differences in the understanding of its personal and social aspects. The personal aspect usually concerns one's ideas and expectations concerning a dignified life. It therefore relates to satisfying one's needs not only at the existential or basic level, but also in a wider sense, including higher-order needs. However, this is not used to assess the poverty of one's environment. Then, people have a greater tendency to expect that the satisfaction of their basic needs determines their unfavourable financial situation. The sense of deterioration of the situation on a global or national scale was also observed in studies by other scientists [70-72]. They 
could also be related to the logic of relative deprivation, which was extensively described by [73-77].

\section{Summary}

The main goal of the study was to make a subjective assessment of the social security of households during the coronavirus pandemic. The respondents provided answers to the research questions concerning the perception of their socio-economic situation, which enabled verification of the research hypotheses. In April 2020, i.e., at the first stage of the research, the respondents strongly felt that the financial situation of their households had deteriorated. In June 2020 (stage II) this perception weakened slightly because they may have considered the pandemic situation to be temporary. However, in September 2020 (stage III) the sense of the possible deterioration of their financial situation increased again due to the ongoing pandemic and its consequences. The analyses enabled the verification of the first research hypothesis (H1), which indicated that during the pandemic the respondents strongly felt that the financial situation of their households had deteriorated. However, this feeling was strong only at the first stage of the research.

The second research question concerned family poverty. In April 2020, more than four in five respondents thought that the poverty of families in Poland might increase. In June and September 2020, the respondents were more optimistic and only two in three of them expressed their concern in this respect. Thus, the second research hypothesis (RH2), which assumed that the respondents' perception of poverty in their households would increase during the pandemic, could not be positively verified.

The next research question was related to the sense of job security. In April 2020, about a fifth of the respondents thought that they could lose their jobs. At the next two stages of the research-in June and September 2020-the respondents were more optimistic. It is important to add that the respondents were surprisingly firmly convinced that unemployment in Poland would increase. In April 2020, as many as nine in ten respondents thought that it would increase. At the subsequent stages of the research, their assessments were slightly less pessimistic. The verification of the third research hypothesis (RH3) concerning the respondents' fears of losing their jobs and increasing unemployment in Poland revealed a considerable difference between the percentage of the people who feared higher unemployment in Poland and those who felt that they would lose their jobs. The respondents were far more afraid of higher unemployment in Poland than losing their jobs.

The last research question concerned the respondents' assessment of the level of uncertainty of the future situation of their households and the situation in Poland. The fourth research hypothesis (RH4) assumed that during the period under analysis, the respondents' level of uncertainty about the future financial situation of their families and the situation in Poland was high. It is noteworthy that at each stage of the research, the respondents' sense of uncertainty about the situation of their families was at the medium level. On the other hand, in the first stage of the research, the respondents felt very highly uncertain of the situation in Poland. At the next two stages of the research, their sense of uncertainty decreased to a high level, which only partially confirmed the fourth research hypothesis.

One of the most important research conclusions is the dichotomy in the respondents' feelings. There was a noticeable difference between what they thought about their socioeconomic situation and what they thought about the situation in Poland. The respondents were more radical in their assessments of the changes they expected in their environment rather than in themselves. At the same time, the respondents' attitude changed noticeably between stages I, II, and III.

\section{Recommendations}

The COVID-19 pandemic has affected households all around the world. This article presents research on the respondents' subjective assessment of the social security of their 
households and their estimations of the level of uncertainty about the future situation of their households and the situation in Poland during the COVID-19 crisis. Our procedure provided estimates which can be useful in national analyses, and they may also inspire research in other countries. The research makes it possible to monitor the situation of households in Poland during the COVID-19 pandemic. We assumed that our research can be repeated, as it concerns a broader issue of the situation of households in Poland, especially in terms of perceived poverty.

The message of this article is also to show that the new public policies which are currently being introduced have positive but insufficient effects on households, and that it is necessary to increase their effectiveness. It is therefore very important to search for new solutions through various analyses and research paths concerning the situation of households, including their subjective assessment of social security. This message also applies to other developing countries and will be particularly important if further restrictions are introduced on business in the future, with new negative consequences for households. If new lockdowns and restrictions are not accompanied by adequate social programmes, they are less likely to be widely accepted by society and will have significant consequences for households experiencing problems. For this reason, the results of this study may help to shape the right policy to mitigate the consequences of the COVID-19 pandemic.

Author Contributions: Conceptualization, S.K. and A.Ł.; methodology, S.K. and A.Ł.; validation, S.K. and A.Ł.; formal analysis, S.K. and A.Ł.; investigation, S.K. and A.Ł.; resources, S.K., and A.Ł.; data curation, S.K. and A.Ł.; writing-original draft preparation, S.K., A.Ł. and A.K.; writing-review and editing, S.K., A.Ł. and A.K.; visualization, S.K. and A.Ł.; supervision, S.K. and A.Ł.; project administration, S.K. and A.Ł.; funding acquisition, S.K., A.Ł. and A.K. All authors have read and agreed to the published version of the manuscript.

Funding: The research was financed from resources of the Faculty of Economics, Poznan University of Life Sciences.

Institutional Review Board Statement: Not applicable.

Informed Consent Statement: Not applicable.

Data Availability Statement: Not applicable.

Conflicts of Interest: The authors declare no conflict of interest.

\section{References}

1. Bauman, Z. Liquid Modernity; Polity Press: Cambridge, UK, 2000.

2. Ahsan, M.M.; Sadak, C. Exploring housing market and urban densification during COVID-19 in Turkey. J. Urban Manag. 2021, 10, 218-229. [CrossRef]

3. Hu, M.R.; Lee, A.D.; Zou, D. COVID-19 and housing prices: Australian evidence with daily hedonic returns. Financ. Res. Lett. 2021, 43, 101960. [CrossRef]

4. Denysov, O.; Litvin, N.; Lotariev, A.; Yegorova-Gudkova, T.; Akimova, L.; Akimov, O. Management of State Financial Policy in the Context of the COVID-19 Pandemic. Ad Alta J. Interdiscip. Res. 2021, 11, 52-57. Available online: http://www.magnanimitas. cz/ADALTA/110220/papers/A_09.pdf (accessed on 17 January 2022).

5. Meyer, V.; Caporal, J. The Shifting Roles of Monetary and Fiscal Policy in Light of COVID-19; Center for Strategic and International Studies (CSIS): Washington, DC, USA, 2021. Available online: https:/ / www.csis.org/analysis/shifting-roles-monetary-andfiscal-policy-light-covid-19 (accessed on 17 January 2022).

6. Dudek, M.; Śpiewak, R. Effects of the COVID-19 Pandemic on Sustainable Food Systems: Lessons Learned for Public Policies? The Case of Poland. Agriculture 2022, 12, 61. [CrossRef]

7. Wojciechowska-Solis, J.; Barska, A. Exploring the Preferences of Consumers' Organic Products in Aspects of Sustainable Consumption: The Case of the Polish Consumer. Agriculture 2021, 11, 138. [CrossRef]

8. Śmiglak-Krajewska, M.; Wojciechowska-Solis, J. Consumer versus Organic Products in the COVID-19 Pandemic: Opportunities and Barriers to Market Development. Energies 2021, 14, 5566. [CrossRef]

9. Muça, E.; Pomianek, I.; Peneva, M. The Role of GI Products or Local Products in the Environment-Consumer Awareness and Preferences in Albania, Bulgaria and Poland. Sustainability 2022, 14, 4. [CrossRef]

10. Hromada, E.; Cermakova, K. Financial unavailability of housing in the Czech Republic and recommendations for its solution. Int. J. Econ. Sci. 2021, 10, 47-57. [CrossRef] 
11. Cecrdlova, A. Comparison of the approach of the Czech National Bank and the European Central Bank to the effects of the global financial crisis. Int. J. Econ. Sci. 2021, 10, 18-46. [CrossRef]

12. Chin, W.L.; Fatimahwati Pehin Dato Musa, S. Agritourism resilience against COVID-19: Impacts and management strategies. Cogent Soc. 2021, 7, 1950290. [CrossRef]

13. Kock, F.; Nørfelt, A.; Josiassen, A.; Assaf, A.G.; Tsionas, M.G. Understanding the COVID-19 tourist psyche: The Evolutionary Tourism Paradigm. Ann. Tour. Res. 2020, 85, 103053. [CrossRef] [PubMed]

14. Shakibaei, S.; de Jong, G.C.; Alpkökin, P.; Rashidi, T.H. Impact of the COVID-19 pandemic on travel behavior in Istanbul: A panel data analysis. Sustain. Cities Soc. 2020, 65, 102619. [CrossRef] [PubMed]

15. Zheng, R.; Yu, X.; Wang, W.; Ning, G.; Bi, Y. Spatial transmission of COVID-19 via public and private transportation in China. Travel Med. Infect. Dis. 2020, 34, 101626. [CrossRef] [PubMed]

16. Asmundson, G.J.G.; Taylor, S. Coronaphobia: Fear and the 2019-nCoV outbreak. J. Anxiety Disord. 2020, 70, 102196. [CrossRef]

17. Chulasiri, P.; Ruwanpathirana, T.; Gunawardena, N.; Wickramasinghe, C.; Lokuketagoda, B. Perceptions of the current COVID situation and health, social and economic impact of the current scenario among a rural setting in Anuradhapura district. J. Postgrad. Inst. Med. 2020, 7, E123 1-13. [CrossRef]

18. Halamska, M. Rural crumbs of the pandemic: Communities and their institutions. Introduction to the thematic issue. Wies Roln 2020, 3, 12-16. Available online: https:/ / kwartalnik.irwirpan.waw.pl/wir/article/view/750/680 (accessed on 6 May 2021).

19. Hall, M.C.; Prayag, G.; Fieger, P.; Dyason, D. Beyond panic buying: Consumption displacement and COVID-19. J. Serv. Manag. 2021, 32, 113-128. [CrossRef]

20. Kalinowski, S. Od paniki do negacji: Zmiana postaw wobec COVID-19 (From panic to denial: Changing attitudes towards COVID-19). Wieś Roln. 2020, 3, 45-65. [CrossRef]

21. Kalinowski, S.; Wyduba, W. Moja Sytuacja w Okresie Koronawirusa. Raport Końcowy (My Situation during the Coronavirus Period. Final Report); Instytut Rozwoju Wsi i Rolnictwa PAN: Warszawa, Poland, 2020. Available online: http:/ /admin2.irwirpan.waw. pl/dir_upload/site/files/IRWiR_PAN/Raport_Koncowy_IRWiR.pdf (accessed on 6 May 2021).

22. McCarthy, J.U.S. Coronavirus Concerns Surge, Government Trust Slides. Gallup News: Politics 2020, Published Electronically March 16. Available online: https://news.gallup.com/poll/295505/coronavirus-worries-surge.aspx (accessed on 6 May 2021).

23. Naeem, M. Do social media platforms develop consumer panic buying during the fear of COVID-19 pandemic. J. Retail. Consum. Serv. 2021, 58, 102226. [CrossRef]

24. Nolting, T. COVID-19 (SARS-CoV-2) in Germany: A Holistic Approach: A Communication-Psychological, Socio-Philosophical and Biomedical Analysis of the Pandemic. Release: 20 May 2020, Duesseldorf, Germany. Update: 1 November 2020, cf. p. 48. Available online: https://www.researchgate.net/publication/345136477_Covid-19_SARS-CoV-2_in_Germany_A_holistic_ approach (accessed on 6 May 2021).

25. Kadeřábková, B.; Jašová, E. How the Czech government got the pandemic wrong. In Proceedings of the 15th Economics and Finance Conference, Prague, Czech Republic, 21-22 June 2021; pp. 42-52. [CrossRef]

26. Kalinowski, S.; Łuczak, A. Social (in) security-The ambivalence of villagers' perceptions during COVID-19. Soc. Policy Issues 2021, 54, 48-67. [CrossRef]

27. Knight, F.H. Risk, Unicertainty and Profit; Houghton Mifflin Company: Boston, MA, USA; New York, NY, USA, 1921. Available online: https:/ / fraser.stlouisfed.org/files/docs/publications/books/risk/riskuncertaintyprofit.pdf (accessed on 6 May 2021).

28. Beck, U. Społeczeństwo Ryzyka. W Drodze Do Innej Nowoczesności, 2nd ed.; Original Work: Risikogesellschaft, Published 2000; Cieśla, S., Translator; Wydawnictwo Naukowe Scholar: Warszawa, Poland, 2004.

29. Zalega, T. Konsumpcja w Gospodarstwach Domowych o Niepewnych Dochodach (Consumption in Households with Precarious Income); Wydawnictwo Uniwersytetu Warszawskiego: Warszawa, Poland, 2008.

30. Kalinowski, S. Pewni niepewności (Confident in uncertainty). In Życie na Skraju—Marginesy Społeczne Wielkiego Miasta (Living on the Edge-The Social Margins of a Big City); Galor, Z., Goryńska-Bittner, B., Kalinowski, S., Eds.; Societas Pars Mundi: Bielefeld, Germany, 2014; pp. 387-404. Available online: http://www.spmpublishing.eu/?zycie-na-skraju-\%E2\%80\%93-marginesyspoleczne-wielkiego-miasta, 8 (accessed on 6 May 2021).

31. Sowińska, A. Strategie zaradcze w sytuacjach utraty bezpieczeństwa socjalnego (Remedial strategies for coping with situation of social security depravation). In Bezpieczeństwo Socjalne (Social Security); Frąckiewicz, L., Ed.; Wydawnictwo AE im. Karola Adamieckiego: Katowice, Poland, 2003; pp. 105-119.

32. Charles, G.; Anderson-Nathe, B. Uncertainty in the time of coronavirus. Child Youth Serv. 2020, 41, 1-2. [CrossRef]

33. Coibion, O.; Gorodnichenko, Y.; Weber, M. Labor Markets during the COVID-19 Crisis: A Preliminary View; NBER Working Paper Series, No. 27017; National Bureau of Economic Research: Cambridge, MA, USA, 2020. [CrossRef]

34. DiNapoli, T.P. Under Pressure: Local Government Revenue Challenges during the COVID-19 Pandemic; Office of the New York State Comptroller: New York, NY, USA, 2020. Available online: https://www.osc.state.ny.us/files/local-government/publications / pdf/local-government-revenue-challenges-during-covid-19-pandemic.pdf (accessed on 24 June 2021).

35. Zwęlińska-Gałecka, D. Koronakryzys. Lokalne zróżnicowanie globalnej pandemii (The coronavirus crisis: Local responses to the global pandemic). Wieś Roln. 2020, 3, 67-90. [CrossRef]

36. Almeida, V.; Barrios, S.; Christl, M.; de Poli, S.; Tumino, A.; van der Wielen, W. The impact of COVID-19 on households' income in the EU. J. Econ. Inequal. 2021, 19, 413-431. [CrossRef] [PubMed] 
37. Hromada, E.; Čermáková, K.; Krulický, T.; Machová, V.; Horák, J.; Mitwallyova, H. Labour Market and Housing Unavailability: Implications for Regions Affected by Coal Mining. Acta Montan. Slovaca 2021, 26, 404-414.

38. Dudek, H. Households' food insecurity in the V4 countries: Microeconometric analysis. Amfiteatru Econ. 2019, $21,377-392$. [CrossRef]

39. Łuczak, A.; Kalinowski, S. Assessing the level of the material deprivation of European Union countries. PLoS ONE 2020, 15, 0238376. [CrossRef]

40. Power, M.; Doherty, B.; Pybus, K.J.; Pickett, K.E. How COVID-19 has exposed inequalities in the UK food system: The case of UK food and poverty [version 1; peer review: 3 approved, 2 approved with reservations]. Emerald Open Res. 2020, 2, 11. [CrossRef]

41. Dudek, H.; Szczesny, W. Multi-dimensional material deprivation in the Visegrád Group: Zero-inflated beta regression modelling. In Analysis of Socio-Economic Conditions: Insights from a Fuzzy Multi-Dimensional Approach; Betti, G., Lemmi, A., Eds.; Routledge: London, UK, 2021; pp. 151-165. [CrossRef]

42. Dickerson, J.; Kelly, B.; Lockyer, B.; Bridges, S.; Cartwright, C.; Willan, K.; Shire, K.; Crossley, K.; Bryant, M.; Sheldon, T.A.; et al Experiences of lockdown during the COVID-19 pandemic: Descriptive findings from a survey of families in the Born in Bradford study [version 2; peer review: 2 approved]. Wellcome Open Res. 2021, 5, 228. [CrossRef]

43. González, F.A.I.; Santos, M.E.; London, S. Multidimensional poverty and natural disasters in Argentina (1970-2010). J. Hum. Dev. Capab. 2021. [CrossRef]

44. Kalinowski, S. My Situation during the Coronavirus Pandemic; Unpublished source material in Polish; Institute of Rural and Agricultural Development of the PAS: Warsaw, Poland, 2020.

45. Statistics Poland [GUS]. Household Budget Survey in 2019; Statistics Poland, Social Surveys Department: Warsaw, Poland, 2020. Available online: https://stat.gov.pl/en/topics/living-conditions/living-conditions/household-budget-survey-in-2019,2,14. html (accessed on 6 May 2021).

46. Sobczyk, M. Statystyka Opisowa (Descriptive Statistic); Wydawnictwo C.H. Beck: Warszawa, Poland, 2010.

47. Chen, C.-T. Extensions of the TOPSIS for group decision-making under fuzzy environment. Fuzzy Sets Syst. 2000, 114, 1-9. [CrossRef]

48. Triantaphyllou, E. Multi-Criteria Decision Making Methods: A Comparative Study; Applied Optimization; Springer: Boston, MA, USA, 2000; Volume 44. [CrossRef]

49. Chen, M.-F.; Tzeng, G.-H. Combining grey relation and TOPSIS concepts for selecting an expatriate host country. Math. Comput. Model. 2004, 40, 1473-1490. [CrossRef]

50. Chang, Y.-H.; Yeh, C.-H. A new airline safety index. Transport. Res. B-Meth. 2004, 38, 369-383. [CrossRef]

51. Roszkowska, E.; Wachowicz, T. Application of fuzzy TOPSIS to scoring the negotiation offers in ill-structured negotiation problems. Eur. J. Oper. Res. 2015, 242, 920-932. [CrossRef]

52. Acuña-Soto, C.M.; Liern, V.; Pérez-Gladish, B. Normalization in TOPSIS-based approaches with data of different nature: Application to the ranking of mathematical videos. Ann. Oper. Res. 2021, 296, 541-569. [CrossRef]

53. Wysocki, F. Metody Taksonomiczne w Rozpoznawaniu Typów Ekonomicznych Rolnictwa i Obszarów Wiejskich (Taxonomic Methods in Recognizing Economic Types of Agriculture and Rural Areas); Wydawnictwo Uniwersytetu Przyrodniczego: Poznań, Poland, 2010.

54. McKay, S.; Rowlingson, K. The aims of social security. In Social Security in Britain; McKay, S., Rowlings, K., Eds.; Palgrave: London, UK, 1999; pp. 1-21. [CrossRef]

55. Webb, D.; Wills-Herrera, E. Introduction. In Subjective Well-Being and Security; Social Indicators Research Series; Webb, D., Wills-Herrera, E., Eds.; Springer: Berlin, Germany, 2012; Volume 46, pp. 1-11. [CrossRef]

56. StatSoft Polska. Statistica 13.3 Zestaw Plus Wersja 5.0.80 2021; StatSoft Polska: Kraków, Poland, 2021.

57. Ceballos Martin, B.A. FuzzyMCDM: Multi-Criteria Decision Making Methods for Fuzzy Data. R Package Version 1.1. 2016. Available online: https:/ /CRAN.R-project.org/package=FuzzyMCDM (accessed on 6 May 2021).

58. R Core Team. R: A Language and Environment for Statistical Computing; R Foundation for Statistical Computing: Vienna, Austria, 2020. Available online: https:/ / www.R-project.org/ (accessed on 6 May 2021).

59. Łuczak, A.; Kalinowski, S. Fuzzy Clustering Methods to Identify the Epidemiological Situation and Its Changes in European Countries during COVID-19. Entropy 2022, 24, 14. [CrossRef]

60. Holman, E.A.; Garfin, D.R.; Silver, R.C. Media's role in broadcasting acute stress following the Boston Marathon bombings. Proc. Natl. Acad. Sci. USA 2014, 111, 93-98. [CrossRef]

61. Van den Bulck, J.; Custers, K. Television exposure is related to fear of avian flu, an Ecological Study across 23 member states of the European Union. Eur. J. Public Health 2009, 19, 370-374. [CrossRef]

62. Latour, B. Przedmioty Także Posiadają Sprawczość (Objects Too Have Agency). In Teoria Wiedzy o Przeszłości na tle Współczesnej Humanistyki. Antologia (Theory of Knowledge of the Past and the Contemporary Human and Social Sciences); Domańska, E., Ed.; Derra, A., Translator; Wydawnictwo Poznańskie: Poznań, Poland, 2010; pp. 525-560.

63. Kahneman, D. Objective happiness. In Well-Being: Foundations of Hedonic Psychology; Kahneman, D., Diener, E., Schwarz, N., Eds.; Russell Sage Foundation: New York, NY, USA, 1999; pp. 3-25.

64. Van Praag, B.M.S.; Frijters, P. The measurement of welfare and well-being: The Leyden approach. In Well-Being: Foundations of Hedonic Psychology; Kahneman, D., Diener, E., Schwarz, N., Eds.; Russell Sage Foundation: New York, NY, USA, 1999 ; pp. 413-433.

65. Michoń, P. Ekonomia Szczęścia (The Economics of Happiness); Wydawnictwo Harasimowicz: Poznań, Poland, 2010. Available online: https:/ /www.wbc.poznan.pl/dlibra/publication/242598/edition/202243/ (accessed on 6 May 2021). 
66. Zaleśkiewicz, T. Psychologia Ekonomiczna (Economic Psychology); Gdańskie Wydawnictwo Psychologiczne: Gdańsk, Poland, 2013.

67. Strube, M.J.; Lott, C.L.; Lê-Xuân-Hy, G.M.; Oxenberg, J.; Deichmann, A.K. Self-evaluation of abilities: Accurate self-assessment versus biased self-enhancement. J. Pers. Soc. Psychol. 1986, 51, 16-25. [CrossRef]

68. Koźmiński, A.K.; Zagórski, K. Społeczeństwo w czasach kryzysu i niepewności ekonomicznej. Założenia, pojęcia, hipotezy (Society in times of crisis and economic uncertainty: Assumptions, concepts, hypotheses). In Postawy Ekonomiczne w Czasach Niepewności. Ekonomiczna Wyobraźnia POLAKÓW 2012-2014 (Economic Attitudes in Times of Uncertainty. Economic Imagination of Poles 2012-2014); Zagórski, K., Koźmiński, A.K., Morawski, W., Piotrowska, K., Rae, G., Strumińska-Kutra, M., Eds.; Wydawnictwo Naukowe Scholar: Warszawa, Poland, 2015; pp. 9-20.

69. Smith, V.L. Rationality in Economics: Constructivist and Ecological Forms; Cambridge University Press: New York, NY, USA, 2007. [CrossRef]

70. Baldwin, R.; Weder di Mauro, B. (Eds.) Economics in the Time of COVID-19; CEPR Press: London, UK, 2020. Available online: https:/ / voxeu.org/article/economics-time-covid-19-new-ebook (accessed on 6 May 2021).

71. Djankov, S.; Panizza, U. Developing economies after COVID-19: An introduction. In COVID-19 in Developing Economies; Djankov, S., Panizza, U., Eds.; CEPR Press: London, UK, 2020; pp. 8-23. Available online: https://voxeu.org/content/covid-19-developingeconomies (accessed on 6 May 2021).

72. Valensisi, G. COVID-19 and global poverty: Are LDCs being left behind? Eur. J. Dev. Res. 2020, 32, 1535-1557. [CrossRef]

73. Runciman, W.G. Problems of research on relative deprivation. Arch. Eur. Sociol. 1961, 2, 315-323. Available online: http: / / www.jstor.org/stable/23987944 (accessed on 6 May 2021). [CrossRef]

74. Gurney, J.N.; Tierney, K.J. Relative deprivation and social movements: A critical look at twenty years of theory and research. Sociol. Q. 1982, 23, 33-47. Available online: http:/ /www.jstor.org/stable/410635 (accessed on 6 May 2021). [CrossRef]

75. Boudon, R. Effets Pervers et Ordre Social; Quadrige/Presses Universitaires de France: Paris, France, 1993.

76. Stiglitz, J.E. The Price of Inequality: How Today's Divided Society Endangers Our Future; W.W. Norton \& Company: New York, NY, USA, 2012.

77. Grasso, M.T.; Yoxon, B.; Karampampas, S.; Temple, L. Relative deprivation and inequalities in social and political activism. Acta Polit. 2019, 54, 398-429. [CrossRef] 